\title{
Serenoa repens, selenium and lycopene to manage lower urinary tract symptoms suggestive for benign prostatic hyperplasia
}

\section{Andrea Russo, Paolo Capogrosso, Giovanni La Croce, Eugenio Ventimiglia, Luca Boeri, Alberto Briganti, Rocco Damiano, Francesco Montorsi \& Andrea Salonia}

To cite this article: Andrea Russo, Paolo Capogrosso, Giovanni La Croce, Eugenio Ventimiglia, Luca Boeri, Alberto Briganti, Rocco Damiano, Francesco Montorsi \& Andrea Salonia (2016): Serenoa repens, selenium and lycopene to manage lower urinary tract symptoms suggestive for benign prostatic hyperplasia, Expert Opinion on Drug Safety, DOI: 10.1080/14740338.2016.1190830

To link to this article: http://dx.doi.org/10.1080/14740338.2016.1190830

Accepted author version posted online: 27

May 2016.

Published online: 27 May 2016.

Submit your article to this journal $₫$

\section{凹 Article views: 3}

View related articles

View Crossmark data \lceil 
Publisher: Taylor \& Francis

Journal: Expert Opinion on Drug Safety

DOI: $10.1080 / 14740338.2016 .1190830$

Serenoa repens, selenium and lycopene to manage lower urinary tract symptoms suggestive for benign prostatic hyperplasia

A ndrea Russo ${ }^{1,2}$, Paolo Capogrosso ${ }^{1,2}$, Giovanni La Croce ${ }^{1,2}$, Eugenio Ventimiglia, MD ${ }^{1,2}$, Luca Boeri ${ }^{2}$,Alberto Briganti ${ }^{1,2,3}$, Rocco Damiano ${ }^{3}$, Francesco Montorsi ${ }^{1,2}$ A ndrea Salonia, 1,2

${ }^{1}$ U niversità V ita-Salute San R affaele, M ilan, Italy

${ }^{2}$ Division of Experimental Oncology/U nit of U rology; URI; IRCCS Ospedale San Raffaele, M ilan, Italy

${ }^{3}$ Research D octorate Program in U rology, M agna Graecia U niversity, Catanzaro, Italy

\section{CORRESPONDING AUTHOR:}

A ndrea Salonia, M D, PhD

University V ita-Salute San R affaele

Division of Experimental Oncology/U nit of U rology; URI-U rological Research Institute IRCCS Ospedale San Raffaele

$\checkmark$ ia Olgettína 60

20132 M ilan, Italy

Tel. +390226435506

Fax +3902 26432969

Email:salonia.andrea@hsr.it 


\section{ABSTRACT}

INTRODUCTION: Benign prostatic hyperplasia (BPH) is a disease affecting most of the elderly male. \pm 1-blockers and 5 -alpha reductase inhibitors are currently used to target lower urinary tract symptoms (LUTS). Moreover phytotherapeutic agents, including Serenoa Repens (SeR), have shown to have a role in ameliorating BPH/LUTS al one or in combination of other elements like Selenium (Se) and Lycopene ( $L y)$.

AREAS COVERED: A literature review was performed using data from articles assessing the role of of SeR+Se+Ly in the management of LUTS secondary to BPH. Diverging evidence on SeR's efficacy is available. On one hand several studies have shown SeR efficacy in treating BPH/LUTS. SeR is effective in reducing prostate size, urinary frequency, dysuria, nocturia and in improving maximum urine flow-rate. On the other hand two longterm trials reported that SeR did not improve prostate size or urinary flow. SeR $+\mathrm{Se}+\mathrm{L}$ y in combination with tamsulosin is more effective than single therapies in improving IPSS and increasing maximal urinary flow-rate in patients affected by LUTS/BPH.

EXPERT OPINION: Despite great amount of preclinical and clinical studies, the use of SeR in BPH/LUTS is not sustained by clear evidence for a therapeutic efficacy but current data hint higher efficacy of of SeR + Se+L y compared to SeR alone.

\section{KEY WORDS}

BPH, Serenoa Repens, Phytotherapy, Prostate Inflammation, LUTS 


\section{INTRODUCTION}

Benign prostatic hyperplasia $(\mathrm{BPH})$ is probably the most common proliferative diseases affecting the elderly male ${ }^{1}$. BPH is characterized by epithelial and smooth muscle proliferation primarily within the prostatic transition zone that may lead to a wide spectrum of problems; lower urinary tract symptoms (LUTS) related to BPH (LUTS/BPH) are the most frequent ${ }^{1}$.

The pathogenesis of $\mathrm{BPH}$ is not fully understood, even though the large burden of $\mathrm{BPH}$ on public health ${ }^{2}$. A ge-related systemic/local hormonal and vascular changes appear to represent the main mechanism. However, a growing body of evidence suggests that the inflammatory cascade may play a key role in the development and progression of $\mathrm{BPH}^{2,3}$. Inflammation may contribute to tissue injury, and cytokines produced by inflammatory cells may stimulate local growth factor production and angiogenesis ${ }^{4}$. As a consequence, the development of an inflammatory cascade has al so suggested to have a role in prostate cancer ${ }^{5}$.

Furthermore, the development of abnormal prostate growth may involve disruption of dihydrotestosterone (DHT)- supported homeostasis between cell proliferation and cell death, and, as a result, proliferative processes predominate and apoptotic processes are inhibited ${ }^{6,7}$. The key role of DHT in the development of BPH led to the development of 5-alpha reductase inhibitors (5ARIS) as a treatment for $\mathrm{BPH}$, and potentially, for the prevention of prostate cancer ${ }^{6}$. Various large trials have shown the efficacy of alpha-blockers when used alone and/or in combination with $5 \mathrm{ARIS}$ in $\mathrm{BPH}{ }^{8}$. M oreover, none of the data has demonstrated the benefit of anti-muscarinic medications in specific populations who suffer from bladder outlet obstruction (BOO) causing storage urinary symptoms ${ }^{9}$. However, these therapeutic strategies are not completely free from side effects on sexuality and blood pressure regulation ${ }^{10,11}$ and it not easy to identify an effective therapy without side effects. 


\section{SYNTHETIC DRUGS}

A broad spectrum of drugs for the treatment of LUTS is available, ranging from \pm-1 adrenoceptor antagonists ( \pm 1 -blockers), $5 \mathrm{~A}$ R Is, antimuscarinics, the phosphodiesterase type 5 inhibitor (PDE5I) tadalafil, vasopressin analogues and the beta-3-adrenoceptor agonist mirabegron ${ }^{12}$.

A mong those, \pm -1-adrenoceptor antagonists ( \pm 1 -blockers), such as doxazosin, prazosin, terazosin, alfuzosin tamsulosin, and silodosin, are currently considered the first-line medical approach ${ }^{13,14}$. These compounds improve the dynamic component of micturition (activation of bladder smooth muscles) and reduce the symptoms of $\mathrm{BPH}$ in up to $70 \%$ of men. They function by relating the muscles located near the prostate, attenuating the annoyance of prostate enlargement ${ }^{15} . \pm 1$-blockers as a group may be associated with an increase in adverse effects such as hypotension, dizziness, somnolence, or syncope. However, adverse effect varies by each individual \pm 1 -blocker ${ }^{13,14,16}$.

Other drugs largely used to treat LUTS/BPH are 5A RIs, namely dutasteride and finasteride ${ }^{13}$, 17-19. These drugs inhibit enzyme 5-t-reductase blocking the conversion of testosterone to DHT, which stimulates growth of prostate gland. Finasteride produces a slow reduction of prostate size and consequently improves urinary symptoms. Six months of continuous treatment are considered of clinical relevance to achieve symptom relief ${ }^{20}$. Finasteride treatment has been associated with a number of unpleasant side effects, thus including erectile dysfunction, reduced libido, and ejaculation problems ${ }^{21,22}$.

According to the EAU guidelines alpha1-blockers can be offered to men with moderate-tosevere LUTS (LE 1a, GR A). 5t-Reductase inhibitors can be offered to men who have

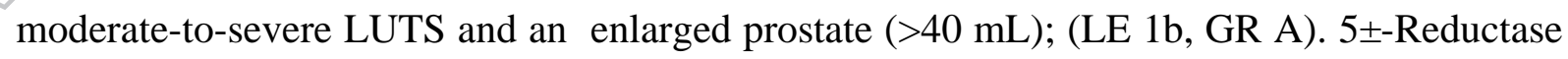
inhibitors can prevent disease progression with regard to acute urinary retention and the need for surgery (LE 1b, GR A). Muscarinic receptor antagonists may be used in men with moderate-to-severe LUTS who mainly have bladder storage symptoms. (LE Ib, GR B). 
PDE5Is reduce moderate-to-severe (storage and voiding) LUTS in men with or without erectile dysfunction. Only tadalafil ( $5 \mathrm{mg}$ once daily) has been licensed for the treatment of male LUTS in Europe. (LE 1a, GR A). V asopressin analogue can be used for the treatment of nocturia due to nocturnal polyuria ( $L E 1 b, G R A$ ). Beta-3 agonists may be used in men with moderate-to-severe LUTS who have predominantly bladder storage symptoms (LE Ib, GR ) $B)^{23}$.

The EAU Guidelines Panel have not made any specific recommendations on phytotherapy for the treatment of male LUTS because of product heterogeneity, limited regulatory framework, and methodological limitations of the published trials and meta-analyses. Phytotherapeutic agents are a heterogeneous group and may contain differing concentrations of the active ingredient(s). Hence, meta-analyses do not seem to be justified and results of any analyses have to be interpreted with caution ${ }^{23}$.

When medical therapy fails to achieve a sustainable quality of life, a surgical reduction of prostate gland is a necessary option ${ }^{13}$.

\subsection{SERENOA REPENS}

Phytotherapeutic agents, including the ripe berries of the A merican dwarf palm (Serenoa Repens, saw palmetto) have been proposed to target genitourinary disorders, to increase sperm production and breast size and to increase diuresis ${ }^{24}$. In numerous European countries phytotherapeutic compounds are widely used ${ }^{25-27}$. A merican Indians used Serenoa Repens (SeR) to deal with genitourinary disturbances and enhance testicular function and breast size ${ }^{25-27}$. In the Unites States, the clinical therapy with phytotherapeutic agents has largely increased and SeR is used by about 2.5 million men affected by LUTS ${ }^{28,29}$.

The mechanisms underlying the pharmacological effects of SeR in BPH are still far from being completely identified ${ }^{30}$. Table 1 summarizes the effects of SeR on prostate. It has been suggested that SeR may inhibit $5 \alpha$-reductase and may have an anti-androgenic, anti- 
proliferative, anti-inflammatory and anti-edema activity ${ }^{29,30}$. These effects are obtained with high doses of SeR and therefore it has been questioned whether these effects have a therapeutic relevance ${ }^{31}$. Alpha-blockers represent a key therapeutic strategy in the management of patient with frequency, urinary incontinence and BPH-related obstruction. It has been demonstrated that SeR may exert anti-adrenergic receptors activity ${ }^{32}$. SeR interacts with the adrenergic and muscarinic receptors localized in the lower urinary tract, and lessens the obstructive symptoms following BPH ${ }^{33}$. Prostate growth and development is primed by androgen stimulation and DHT plays a key role in both circumstances ${ }^{34}$. DHT is produced from testosterone by $5 \alpha$-reductase, which presents two isoforms, $5 \alpha$ - reductase type 1 and $2^{34}$. The importance of these two isoforms in BPH has not been fully clarified. Finasteride is a 5-alpha-reductase inhibitor, specifically the type II isoenzyme ${ }^{35}$. By inhibiting 5a-reductase, finasteride prevents conversion of testosterone to DHT by the type II isoenzyme, resulting in a decrease in serum DHT levels by about $65-70 \%$ and in prostate DHT levels by up to $85-$ $90 \%$, where expression of the type II isoenzyme dominates ${ }^{36}$. Unlike dual inhibitors of both isoenzymes of $5 \pm$-reductase which can reduce DHT levels in the entire body by more than $99 \%$, finasteride does not completely suppress DHT production because it lacks significant inhibitory effects on the $5 \pm$-reductase type I isoenzyme, with 100-fold less affinity for type I as compared to type ${ }{ }^{37}$. In addition to blocking the type II isoenzyme, finasteride competitively inhibits the $5^{2}$-reductase type II isoenzyme, though this is not believed to affect androgen metabolism ${ }^{37}$. Dutasteride inhibits both type 1 and type 2 5̈̈-reductase isoenzymes. Dutasteride suppresses DHT levels more effectively than a selective type 2 inhibitor ${ }^{38}$. However, the clinical role of dual inhibition remains unclear. It has been reported that SeR blocks both isoforms in a non-competitive fashion ${ }^{39}$.

Inflammation has been frequently reported in both human and experimental $\mathrm{BPH}{ }^{30}$ and a major anti-inflammatory effect has been proposed for SeR. M ore specifically, it is possible that SeR interferes with several inflammatory mediators. In fact SeR has both anti- 
inflammatory and anti-oedematous activity in vivo ${ }^{30,40}$. It was shown also that SeR may reduce the production of cyclooxygenase and 5 -lipoxygenase metabolites ${ }^{40}$. It was recently shown that an hexanic lipidosterolic extract of SeR may inhibit monocyte chemoattractant protein-1/Chemokine (C-C) motif ligand 2 (MCP-1/CCL/2) which stimulates monocyte recruitment and activation during inflammation ${ }^{41}$.

A poptosis has a key role in maintaining a constant number of cells and stands as protection mechanism against several diseases and in the development of cancer. Changes in the balance between cell proliferation and programmed cell death leads to an increase in prostate size. A significant increase in Transforming Growth Factor- $\beta$ (TGF-ß), an anti-proliferative cytokine, in the epithelial cells of BPH specimens compared with the normal prostate tissue has been shown ${ }^{42}$. Proliferation exceeding apoptosis has been shown in the stroma and in the prostate epithelium in patients with $\mathrm{BPH}{ }^{43}$. Moreover, treatment with SeR caused a considerable reduction in the proliferative rate and a increase in the apoptotic rate in the $\mathrm{BPH}$ specimens ${ }^{43}$. lii Colado-V elázquez et al investigated the effects of a lipidic extract of Serenoa repens, in markers of oxidative stress, inflammation, and growth factors, in obese rats with testosteroneinduced prostatic hyperplasia 44 . Total nitrites, malondialdehyde, total glutathione, superoxide dismutase (SOD), and catal ase activity were measured; in addition, assays for inflammatory cytokines TNF- $\pm, I L-1^{2}, I L-6$ and the growth factors basic fibroblast growth factor (FGFb) and vascular endothelial growth factor (VEGF) were performed. The obese rats had a higher prostate weight compared with controls. Serenoa

weight, total nitrites, and malondialdehyde; improved total glutathione, SOD, and catalase activity; and significantly reduced inflammatory (TNF-, $\pm I L-1^{2}$ and IL -6$)$ and growth factors (VEGF and FGFb). Serenoa repens showed high antioxidant and antiinflammatory activity in obese rats, suggesting that their use could be beneficial in the treatment of benign prostatic hyperplasia ${ }^{44}$. 


\subsection{SELENIUM}

Selenium (Se) is a trace mineral essential in the diet of humans ${ }^{45}$. The major dietary sources of Se are plant foods and the intake of Se in diet depends on the soil Se concentrations, the types and amounts of food consumed and factors which regulate Se uptake. Food sources of Se include brazilian nuts, fish, whole grains, wheat germ, soybean and sunflower seeds ${ }^{46}$. In human body, the highest Se concentrations are in the liver, kidneys and thyroid gland. Selenium is usually integrated into proteins to form selenoproteins as glutathione peroxidases, thioredoxin reductases, and iodothyronine deiodinases which are involved in several biological functions in both animals and humans.

Human Se deficiency is rare but may occur in some countries where soil concentration of Se is low ${ }^{47}$. Selenium deficiency has also been described in people who received total parenteral nutrition ${ }^{48}$. Selenium deficiency may contribute to the development of heart disease, hypothyroidism, and a weakening of the immune system ${ }^{49}$. Selenium supplementation can reduce the incidence of many types of cancer when non-toxic doses are provided to the diet of rodent species by inhibiting cell proliferation and stimulating apoptosis ${ }^{50}$. Table 1 describes the effects of Se on prostate. A daily supplementation containing 200 micrograms of Se could reduce the risk of developing prostate, lung, and colorectal cancer ${ }^{51}$. M oreover, Harvard's Health Professionals Follow-up Study ${ }^{52}$ assessed human toenail clippings for Se concentration. After six years it was found that men with the highest Se levels at the beginning of the study had a lower incidence of advanced prostate cancer. The SU.VI.M AX study also reported data on a large population who had taken either a combination of vitamin $E$, vitamin $C, B$-carotene, $\mathrm{Se}$, and zinc or placebo ${ }^{53}$. At 7 years of follow-up, there was a significant reduction in the rate of prostate cancer among men with normal prostate-specific antigen who had taken the antioxidant supplement, but the role of Se is not clear. Indeed, selenoproteins are likely implicated in the protective effects of Se against prostate cancer ${ }^{54}$. Furthermore, Se metabolites such as methylselenol derived from $\gamma$-glutamyl-selenomethyl- 
selenocysteine and selenomethyl- selenocysteine components, identified in certain plants and Se-enriched yeast, could have anti-cancer effects ${ }^{54}$. Data indicate that the beneficial effects of dietary Se in combination with isothiocyanates could be attributed to epigenetic and antioxidant effects. Indeed, the impact of aberrant DNA methylation in addition to modulation of key selenoenzymes, such as gastrointestinal glutathione per-oxidase-2 and thioredoxin reductase-1, could be important in the cancer chemoprevention ${ }^{55}$.

\subsection{LYCOPENE}

Lycopene (Ly), a non-provitamin A carotenoid, is a potent antioxid along with the red pigment of tomatoes ${ }^{56}$. Ly is the major active component in tomatoes showing an antioxidant and anti-inflammatory activity twice as effective as $\beta$-carotene and 10 -fold more active than $\alpha$-tocopherol ${ }^{57}$. Lycopene concentrations are known to be high in the prostate gland ${ }^{58}$ and in human semen ${ }^{59}$. It is still under investigation the mechanism by which Ly is sequestered into prostate tissue and then released into semen and the prostatic interstitial space. A study suggested that the packaging of $L y$ into exosomes (the in vitro analogs of prostasomes) for export resulted in reduced degradation of this carotenoid, and therefore maximized the effectiveness of delivery to the sites of action ${ }^{60}$. The high concentration of Ly in prostatic tissue is indirectly implicated in the chemoprevention of pathologies, which could affect the prostate gland in the ageing male, such as slowing the progression of BPH and reducing the risk of developing prostatic cancer. In BPH, these actions may be mediated through a variety of mechanisms including inhibition of cell growth in normal prostatic tissue and induction of apoptosis in hyperplastic prostatic epithelial cells ${ }^{61}$. A number of mechanisms of action are implicated in the ability of $L y$ to prevent the development and progression of prostate cancer, thus including reduction of oxidative DNA damage in prostatic tissue ${ }^{61}$, initiating upregulation of gap-junction proteins (e.g. Connexin 43) to enable improved intercellular communications, and a reduction of local androgen signaling ${ }^{62}$. It was shown that 
testosterone levels in CMO-I knockout mice are dependent on the interaction of the expression of carotenoid cleavage enzymes and the dietary levels of Ly and, in turn, an increased production of lycopenoids in tissue could reduce prostate cancer risk ${ }^{63}$.

Table 1 lists the effects of Ly on prostate. Evidence suggests that a high intake of dietary Ly is associated with a lower risk of prostate cancer (including limiting tumor growth) and cell proliferation ${ }^{64}$. The underlying mechanism could be inhibition of 5 - $\alpha$ reductase and interleukin-6 signaling, as shown in benign prostate tissue of rats ${ }^{65}$. Several evidences indicate that Ly exhibits diverse functions, such as anti-oxidant activity ${ }^{66}$, anti-metastasis ${ }^{67}$, anti-angiogenesis ${ }^{67}$, anti-inflammatory ability ${ }^{68}$ and anticancer ${ }^{69}$. Epidemiological studies hint the evidence for the role of $L y$ as a chemopreventive agent in prostate cancer. $A$ number of these are observational prospective studies that show some correlation between the level of tomato or Ly intake and the relative risk reduction. The Health Professionals Follow-Up Study (47,894 men) showed a strong inverse relationship between the risk of developing prostate cancer and increased consumption of a tomato-enriched $\operatorname{diet}^{70}$.

\subsection{COMBINATION OF SERENOA REPENS, SELENIUM and LYCOPENE}

SeR is often combined with other essential trace element, such as Se and the carotenoid Ly, in order to increase its therapeutic activity in $\mathrm{BPH}$. It has been demonstrated in a $\mathrm{BOO}$ experimental model that a combination of $\mathrm{SeR}$, Se, and $\mathrm{L} y$ is more effective than $\mathrm{SeR}$ al one in reducing prostate inflammatory burden, growth factor expression, oxidative stress and histological features ${ }^{71}$. A suitable rodent model to investigate BPH is achieved via testosterone administration in rats. Prostate enlargement induced by testosterone has been used to assess the effects of potential treatments for BPH, since it reproduces adequately the main features of human $\mathrm{BPH}$, including functional and histological changes. It has been suggested a prominent growth of prostate and an increase in its weight following testosterone administration, showing the typical histological features of $\mathrm{BPH}^{72}$. The combination Se-Ly- 
SeR was more effective than SeR alone in preventing BPH and inhibited growth by $83 \%$, hinting that Se and Ly at pharmacological doses further increase SeR efficacy in BPH. Prostate growth inhibition by Se-Ly-SeR was likely stimulated via both a caspase-dependent signal (through caspase-9) and an independent mechanism involving the pro-apoptotic Bax and the anti-apoptotic $\mathrm{BCl}-2$ gene ${ }^{73}$. Previous findings supported the anti-inflammatory role of Se-Ly-SeR combination in the bladder-obstruction model, in which a significant reduction of inflammatory infiltrate and tumor necrosis factor- $\alpha$, an important BPH inflammatory marker was found ${ }^{71}$. Inflammation growth factors and cytokines play a key role in regulating the normal, hyperplastic and malignant prostatic epithelium. Furthermore, prostatic cells are able to secrete inflammatory mediators and auto-stimulate their own growth. During testosterone-dependent prostate growth, there is an over-expression of the Epidermal Growth Factor (EGF) that was prevented by treatment with Se-Ly-SeR combination. EGF plays a fundamental role in tumorigenesis of the prostate gland ${ }^{74}$ through activation of intracellularsignaling cascades that lead to activation of downstream pathways, cell proliferation, migration, adhesion, anti-apoptosis, angiogenesis, and metastasis ${ }^{75}$. EGF and its receptor EGFR over-expression in prostate cancer is associated with a more aggressive clinical scenario ${ }^{76}$. Furthermore, EGFR inhibition has been reported to decrease $\mathrm{BCl}-2$ expression and to highly increase Bax expression ${ }^{77}$. V ascular endothelial growth factor (VEGF) plays a key role among the growth factors involved in BPH and cancer development. VEGF, frequently named vascular permeability factor, enhances vascular leakage, which in turn contributes to tumor development and metastasis ${ }^{78}$. VEGF has been observed in BPH stromal cells and in prostate cancer epithelial cells, where it plays an important role in tumor growth through angiogenesis ${ }^{79}$. The complex mechanism of apoptosis is an interesting target for the treatment of BPH. Inhibitor of apoptosis proteins (IAPs) modulates apoptosis directly inhibiting caspases ${ }^{80}$. 


\section{EFFICACY}

Saw palmetto has been widely used for treating BPH/LUTS ${ }^{29}$. Two I talian studies on patients with BPH/LUTS have shown that saw palmetto (320 mg/day for 30 days) was effective in reducing prostate size and urinary frequency ${ }^{81}$. A n I ranian study reported that saw palmetto's effectiveness was similar to tamsulosin's and in combination to nettle produced similar effects to finasteride, but with a lower rate of treatment-related side effects ${ }^{82}$. Several studies documented the efficacy of saw palmetto in ameliorating dysuria in men affected with BPH ${ }^{83}$. B oyle et al. ${ }^{84}$ reported positive effects of Permixon ${ }^{\circledR}$ (Pierre Fabre Pharma, Castres, Midi-Pyrénées, France), a lipido-sterolic extract of saw palmetto, in improving maximum urine flow-rate and reducing nocturia compared to placebo. Wilt et al. ${ }^{25}$ tested some saw palmetto preparations (eg, Permixon ${ }^{\circledR}$, Prostagutt ${ }^{\circledR}$ [Dr. Willmar Schwabe GmbH, K arlsruhe, Germany], Prostavigol ${ }^{\circledR}$ [Harras Pharma Curarina A rzneimittel GmbH, M unchen, Germany], etc.) and found positive effects on LUTS and flow parameters.

On the contrary, a review carried out by Tacklind et al. ${ }^{85}$ reported that saw palmetto did not improve prostate size or urinary flow The difference may be the consequence of two longterm trials ${ }^{29,86}$, with a minimum 12 -month trial duration, which was extensively discussed by the Authors. Barry et al. conducted a double-blind, multi-center, placebo-controlled randomized clinical trial ${ }^{86}$. M ore than 350 men were randomized to receive 1,2 , and then 3 pills (320 mg/d) containing a standardized saw palmetto fruit extract with dose escalations at 24 and 48 weeks, or an identical number of placebo pills similarly escalated. A fter 72 weeks the A merican U rological A ssociation Symptom Index (AUASI) score decreased a mean of 2.20 points with saw palmetto extract and 2.99 points with placebo, a group mean difference of 0.79 points favoring placebo $(p=0.91)$. In addition, the analysis of dose response also showed no greater improvement with saw palmetto extract vs. placebo at any dose level. Saw palmetto extract was no better than placebo for participants' global assessments of 
improvement and satisfaction at the end of the study and the quality of life item from the International Prostate Symptom Score (IPSS) ${ }^{86}$. In a double-blind trial conducted by Bent at al. ${ }^{29}$, the authors assigned in an random fashion 225 men over the age of 49 years who had moderate-to-severe LUTS/BPH to one year of treatment with saw palmetto extract (160 mg twice a day) or placebo. There was no significant difference between the saw palmetto and placebo groups in the change in A U ASI scores (mean difference, 0.04 point; $95 \% \mathrm{Cl},-0.93$ to 1.01), maximal urinary flow rate (mean difference, $0.43 \mathrm{ml}$ per minute; $95 \% \mathrm{Cl},-0.52$ to 1.38), prostate size, residual volume after voiding, quality of life, or serum prostate-specific antigen levels during the one-year study ${ }^{29}$. A systematic review carried out by $M$ acD onald et al. reported that the high-quality long-term trials found saw palmetto therapy not superior to placebo in reducing LUTS, even at escalating doses ${ }^{87}$

Carraro et al conducted a 6-month double-blind randomized equivalence study that compared the effects of Serenoa repens (320 mg Permixon) with those of a 5ARI (5 mg finasteride) in 1,098 men with moderate BPH using the IPSS as the primary end-point ${ }^{88}$. B oth Permixon and finasteride decreased the IPSS $(-37 \%$ and $-39 \%$, respectively), improved quality of life (by 38 and $41 \%)$, and increased peak urinary flow rate $(+25 \%$ and $+30 \%, P=0.035)$, with no statistical difference in the percent of responders with a $3 \mathrm{ml} / \mathrm{sec}$ improvement. Finasteride markedly decreased prostate volume (-18\%) and serum PSA levels (-41\%); Permixon improved symptoms with little effect on volume $(-6 \%)$ and no change in PSA levels. Permixon fared better than finasteride in a sexual function questionnaire and gave rise to less complaints of decreased libido and impotence ${ }^{88}$.

Sinescu et al reported a study evalueting the long-term efficacy of treatment with extract of Serenoa repens (Prostamol Uno) in patients with BPH/LUTS ${ }^{89}$. One-hundred-twenty patients with mild or moderate LUTS induced by BPH, maximal urinary flow Q max $<15 \mathrm{ml}$ with a voided volume e150 $\mathrm{ml}, \mathrm{PSA}<4 \mathrm{ng} / \mathrm{ml}$, and residual urinary volume $<150 \mathrm{ml}$ were treated daily for 24 months with one capsule of $320 \mathrm{mg}$ ethanolic extract of Serenoa repens. 
Statistically significant improvements in the IPSS (5.5 points), quality of life (QoL; 1.8 points), $Q(\max )(5.6 \mathrm{ml} / \mathrm{s})$, International Index of Erectile Function (IIEF; 6.4 points) and reduction in residual urinary volume were observed during the study period. The mean prostate volume at 24 months was $36 \mathrm{ml}$, compared to $39.8 \mathrm{ml}$ at baseline. The Authors concluded that long-term treatment with $320 \mathrm{mg}$ ethanolic extract of Serenoa repens proved to be efficient in reducing urinary obstruction, improving symptomatology and QoL of BPH patients ${ }^{89}$.

Pytel et al conducted an open study assessing the efficacy and tolerability of Permixon 160 $\mathrm{mg}$ twice daily administered for 2 years ${ }^{90}$. One hundred fifty-five men with clinically diagnosed BPH and complaints of prostatic symptoms were enrolled in the study. At 6, 12, 18, and 24 months, the IPSS, quality of life, and sexual function score were recorded, and urodynamics and biologic values were measured. IPSS and quality of life improved significantly from baseline at each evaluation time point. At the end of the study and at each evaluation, maximum urinary flow also improved significantly. Prostate size decreased. Sexual function remained stable during the first year of treatment and significantly improved $(P=.001)$ during the second year. Prostate-specific antigen was not affected, and no changes in plasma hormone levels were observed. Improvements in efficacy parameters began at 6 months and were maintained up to 24 months $^{90}$.

M orgia et al. ${ }^{91}$ conducted the PROCOM B trial, a randomized double-blinded, double-dummy multicenter study of 225 patients with an age of 55-80 years old. Participants were randomlyassigned to Se-Ly-SeR, tamsulosin $0.4 \mathrm{mg}$, and Se-Ly-SeR + tamsulosin $0.4 \mathrm{mg}$. The decrease for combination therapy was significantly greater vs. Se-Ly-SeR $(p<0.05)$ and tamsulosin $0.4 \mathrm{mg}(p<0.01)$ for IPSS, respectively, and vs. Se-Ly-SeR $(p<0.01)$ for PVR from baseline to 6 months. A greater decrease in IPSS was observed for the combination group versus Se-LySeR $(p<0.01)$ and increase in maximal urinary flow-rate vs. tamsulosin $0.4 \mathrm{mg}(p<0.01)$, from 6 months to 12 months. At 12 months assessment, the changes of IPSS and maximal urinary 
flow-rate were greater for the combination group vs. both monotherapies (all $p<0.05$ ). The proportions of men with a decrease of at least three points (all $p<0.05$ ) and decrease of $25 \%$ for IPSS (all $p<0.01$ ) were greater for the combination group. Se-Ly-SeR in combination with tamsulosin therapy emerged to be more effective than single therapies in improving IPSS and increasing maximal urinary flow-rate in patients affected by LUTS/BPH ${ }^{91}$.

The efficacy of Se-Ly-SeR (Profluss $®$ ) versus SeR alone was evaluated in patients suffering from category IIIa chronic prostatitis/chronic pelvic pain syndrome (CP/CPPS) ${ }^{92}$. Over 100 patients with IIIa CP/CPPS were randomized into two groups, each to receive SeR al one or in combination for 8 weeks. Mean National Institutes of Health-Chronic Prostatitis Symptom Index (NIH-CPSI) score decreased significantly in both groups. The decrease in the combination group was $-51.64 \%$ while in the SeR alone group was $-26.06 \%$. IPSS improved significantly $(p<0.001)$ in both groups, but more in the combination group. Maximum peak flow rate improved more in patients administered with Se-Ly-SeR ${ }^{92}$.

M orgia et al. conducted a prospective study to evaluate the efficacy of Profluss ${ }^{\circledR}$ (Se-Ly-SeR) on prostatic chronic inflammation ( $\mathrm{PCl})$. They enrolled over 150 men affected by B00/LUTS, submitted to 12-core prostate biopsy for suspected prostate cancer along with 2 more cores collected for PCl evaluation ${ }^{93}$. First group consisted of 108 individuals, with histological diagnosis of PCI associated with B PH and high-grade PIN and/or A SA P (atypical small acinar proliferaton), ${ }^{93}$ randomly assigned to $1: 1$ ratio to daily Profluss ${ }^{\circledR}$ (group I) for 6 months or to control group (group Ic). Second group consisted of 60 men, with histologicallyproven $B P H$, randomly assigned to $1: 1$ ratio to daily Profluss $₫$ in combination with \pm blockers treatment (group II) for 3 consecutive months or to control group (group IIC). A fter 6 months group I underwent a 24-core prostate re-biopsy with 2 more cores for $\mathrm{PCl}$ assessment; similarly, after 3 months group II underwent 2-core prostate biopsy for $\mathrm{PCl}$ analysis. At follow-up there were statistical significant reductions of extension and grading of inflammation, mean values of $C D 20, C D 3, C D 68$, and mean PSA value in group I compared 
to IC, while extension and grading of inflammation were inferior tough not statistically significant in group II as compared with IIc. A statistically significant reduction in the density of $C D 20, C D 3, C D 68, C D 8$ was demonstrated in group II compared to control IIc. Thus, SeLy-SeR may have an anti-inflammatory activity that could be of interest in the treatment of $\mathrm{PCI}$ in BPH and/or PIN/A SA P patients ${ }^{93}$.

\section{SAFETY}

Herbal medicinal products available on the market vary in contents and concentration of their active ingredients. The geographical source of the plant, the time of harvest, plant parts used, type of extract (aqueous, alcoholic, glycerine) as well as delivery forms are key factors in determining fluctuations in the concentration of the active compound ${ }^{94}$. Therefore, considerable differences can be registered in the results of clinical trials of heterogeneous products even when the same botanical species are used ${ }^{95}$. Several randomized controlled trials (RCTs) reported adverse events from Serenoa repens preparations ${ }^{95} ; 14$ of these were placebo-controlled, the remaining 12 studies had active controls of either finasteride, tamsulosin and alfuzosin or no treatment controls. The 14 placebo controlled trials reported the following adverse events: headache, diarrhoea and other gastrointestinal disorders, fatigue, nausea, vomiting and vertigo, cardiovascular complaints, common cold, gastrointestinal bleeding and urinary problems. Stomach upset and diarrhoea were the most commonly reported symptoms. The adverse events reported in the non-placebo-controlled studies were gastralgia, abdominal discomfort, hypertension, decreased libido, impotence, ejaculation disorder, gastrointestinal disorders, rhinitis, headaches, fatigue, dizziness and skin disorders ${ }^{95}$.

No evidence for drug interactions with saw palmetto has been published ${ }^{96}$. Two clinical studies demonstrated that saw palmetto had no significant effect on CY P1A2, CY P2D 6, CY P2E 1, or CY P3A 4 in healthy volunteers ${ }^{97,98}$. Bent et al. ${ }^{29}$ reported that the risk of at 
least one serious TEAE did not differ significantly between the saw palmetto and placebo groups. There were also no significant differences in the mean number of non-serious TEA Es per participant in the saw palmetto and placebo groups or in the change in laboratory values, including testosterone, PSA, and creatinine levels.

\section{EXPERT OPINION}

Inflammation has been reported to have a pivotal role in $\mathrm{BPH}{ }^{30}$ and SeR has been identified as a major anti-inflammatory. SeR shows both anti-inflammatory and anti-oedematous activity ${ }^{30,40}$ as well as it reduces the production of cyclooxygenase and 5-lipoxygenase metabolites ${ }^{40}$ and inhibits monocyte recruitment and activation during inflammation ${ }^{41}$. SeR reduces the proliferative rate and increases the apoptotic rate in the BPH specimens ${ }^{43}$. Se metabolites have shown anti-cancer effects ${ }^{54}$ and cancer chemoprevention effects ${ }^{55}$. Ly exhibits diverse functions, such as anti-oxidant activity ${ }^{66}$, anti-metastasis ${ }^{67}$, antiangiogenesis ${ }^{67}$, anti-inflammatory ability ${ }^{68}$ and anticancer ${ }^{69}$. Ly is involved in the reduction of oxidative DNA damage in prostatic tissue ${ }^{61}$, initiating up-regulation of gap-junction proteins to improve intercellular communications, and a reduction of local androgen signaling ${ }^{62}$. High intake of $L y$ is associated with a lower risk of prostate cancer and cell proliferation ${ }^{64}$, likely via inhibition of 5 - $\alpha$-reductase and interleukin- 6 signaling ${ }^{65}$. Furthermore chronic inflammation is associated with higher prostate volumes, higher PSA values and most importantly higher risk of acute urinary retention $(5.6 \%$ vs $0 \%,<0.05){ }^{99}$. The presence of chronic inflammation is associated with lesser efficacy of medical therapy and the combination Se-Ly-SeR is a pivotal agent to best target LUTS in patient with chronic prostatic inflammation.

SeR efficacy in treating BPH/LUTS has been found in several studies. Two Italian studies demonstrated that SeR was effective in reducing prostate size and urinary frequency ${ }^{81}$. An Iranian study showed that SeR's effectiveness was comparable to tamsulosin's ${ }^{82}$. Several non 
unique studies documented the efficacy of SeR in ameliorating dysuria ${ }^{83}$. Boyle et al. ${ }^{84}$ reported positive effects of SeR in improving maximum urine flow-rate and reducing nocturia compared to placebo. Wilt et al. ${ }^{25}$ tested some SeR preparations and found positive effects on LUTS and flow parameters. Overall, despite great amount of preclinical and clinical research done, the use of SeR in BPH/LUTS is not sustained by clear evidence for a therapeutic efficacy ${ }^{85}$. Important methodological bias of the studies conducted so far are likely to be connected with the diverging evidence available up to now. Larger randomized placebo controlled studies are needed to further asses the efficacy of SeR in BPH.

In order to increase its therapeutic activity in BPH SeR is often combined with Se and Ly. A rodent model of BOO showed that a combination of Se, SeR and $\mathrm{Ly}$ is more effective than SeR alone in reducing inflammation in the prostate ${ }^{71}$. tt was demonstrated in a clinical setting that Se-Ly-SeR in combination with tamsulosin therapy is more effective than single therapies in improving IPSS and increasing maximal urinary flow-rate in patients affected by LUTS/BPH ${ }^{91}$. The efficacy Se-Ly-SeR versus SeR alone was evaluated CP/CPPS ${ }^{92}$. IPSS and M aximum peak flow rate improved more in patients administered with Se-Ly-SeR ${ }^{92}$. A prospective study to evaluate the efficacy of Se-Ly-SeR on PCl showed that Se-Ly-SeR may have an anti-inflammatory activity that could be of interest in the treatment of $\mathrm{PCl}$ in $\mathrm{BPH}$ and/or PIN/A SAP patients ${ }^{93}$. The combination SeR-Se-Ly, along with an increased efficacy, allows a patient-treatment tailoring in the every day clinical practice, especially when combined with al pha-blockers.

Phytotherapeutic products vary in contents and concentration of their active compounds. This heterogeneity could affect the results of clinical trials of dissimilar products even when the same plant species are used ${ }^{95}$. Several randomized controlled trials (RCTs) reported the following adverse events from Serenoa repens preparations ${ }^{95}$ : headache, diarrhoea and other gastrointestinal disorders, fatigue, nausea, vomiting and vertigo, cardiovascular complaints, 
common cold, gastrointestinal bleeding and urinary problems. Gastrointestinal complaints were the most commonly reported symptoms.

Currently large randomized studies are not available to evaluate the efficacy of SeR in BPH. M ethodological bias of the studies conducted so far lead to diverging evidence. There is need for larger randomized placebo controlled studies to better assess SeR $+S e+L y$, but current data hint higher efficacy of of SeR $+\mathrm{Se}+\mathrm{L}$ y compared to SeR alone.

\section{HIGHLIGHTS BOX}

- Phytotherapeutic agents, including Serenoa Repens (SeR), have shown to have a role in ameliorating BPH/LUTS alone or in combination of other elements like Selenium (Se) and L ycopene (Ly).

- SeR is effective in reducing prostate size, urinary frequency, dysuria, nocturia and in improving maximum urine flow-rate.

- SeR + Se+Ly (Profluss $\otimes$ ) in combination with tamsulosin is more effective than single therapies in improving IPSS and increasing maximal urinary flow-rate in patients affected by LUTS/BPH.

- Methodological bias of the studies conducted so far lead to diverging evidence.

- There is need for larger randomized placebo controlled studies to better assess SeR + Se+Ly.

Declaration of Interest

The authors have no relevant affiliations or financial involvement with any organization or entity with a financial interest in or financial conflict with the subject matter or materials discussed in the manuscript. This includes employment, 
consultancies, honoraria, stock ownership or options, expert testimony, grants or patents received or pending, or royalties.

\section{REFERENCES}

\section{Papers of special note have been highlighted as:}

\section{* of interest}

\section{${ }^{* * *}$ of considerable interest}

1. Roehrborn CG. M ale lower urinary tract symptoms (LUTS) and benign prostatic hyperplasia (BPH). The M edical clinics of N orth A merica 2011 lan;95(1):87-100.

2. A bdollah F, B riganti A, Suardi N, Castiglione F, Gallina A, Capitanio U, et al. M etabolic syndrome and benign prostatic hyperplasia: evidence of a potential relationship, hypothesized etiology, and prevention. Korean journal of urology 2011 A ug;52(8):507-16.

3. K ramer $G$, M itteregger $D$, M arberger $M$. Is benign prostatic hyperplasia (BPH) an immune inflammatory disease? Eur U rol 2007 M ay;51(5):1202-16.

4. Lucia MS, Lambert] R. Growth factors in benign prostatic hyperplasia: basic science implications. Curr Urol Rep 2008 J ul; 9(4):272-8.

5. Sharifi N. Steroid receptors aplenty in prostate cancer. N Engl J M ed 2014 M ar $6 ; 370(10): 970-1$

6. Tindall DJ, Rittmaster RS. The rationale for inhibiting 5alpha-reductase isoenzymes in the prevention and treatment of prostate cancer. J U rol 2008 A pr;179(4):1235-42.

7. Hendriksen PJ, Dits NF, K okame K, V eldhoven A, van W eerden W M, Bangma CH, et al. Evolution of the androgen receptor pathway during progression of prostate cancer. Cancer Res 2006 M ay 15;66(10):5012-20. 
8. Roehrborn CG. Clinical management of lower urinary tract symptoms with combined medical therapy. BJU Int 2008 Nov;102 Suppl 2:13-7.

9. Chapple C. A ntimuscarinics in men with lower urinary tract symptoms suggestive of bladder outlet obstruction due to benign prostatic hyperplasia. Curr O pin U rol 2010 Jan;20(1):43-8.

10. Schulman CC. Lower urinary tract symptoms/benign prostatic hyperplasia: minimizing morbidity caused by treatment. U rology 2003 Sep;62(3 Suppl 1):24-33.

11. Gacci M, Ficarra V, Sebastianelli A, Corona G, Serni S, Shariat SF, et al. Impact of medical treatments for male lower urinary tract symptoms due to benign prostatic hyperplasia on ejaculatory function: a systematic review and meta-analysis. J Sex M ed 2014 Jun;11(6):1554-66.

12. Russo A, La Croce G, Capogrosso P, V entimigliaE, Colicchia M, Serino A, et al. Latest pharmacotherapy options for benign prostatic hyperplasia. Expert O pin Pharmacother 2014 Nov;15(16):2319-28.

13. Gratzke C, Bachmann A, Descazeaud A, Drake M J, M adersbacher S, M amoulakis C, et al. EAU Guidelines on the A ssessment of N on-neurogenic M ale L ower U rinary Tract Symptoms including Benign Prostatic Obstruction. Eur U rol 2015 J an 19.

14. Capitanio U, Salonia A, B riganti A, M ontorsi F. Silodosin in the management of lower urinary tract symptoms as a result of benign prostatic hyperplasia: who are the best candidates. Int J Clin Pract 2013 J un;67(6):544-51.

15. Pagano E, Laudato M, Griffo M, Capasso R. Phytotherapy of benign prostatic hyperplasia. A minireview. Phytotherapy research : PTR 2014 Jul;28(7):949-55.

16. Nickel JC, Sander S, M oon TD. A meta-analysis of the vascular-related safety profile and efficacy of alpha-adrenergic blockers for symptoms related to benign prostatic hyperplasia. Int J Clin Pract 2008 Oct;62(10):1547-59. 
17. Edwards JE, M oore RA. Finasteride in the treatment of clinical benign prostatic hyperplasia: a systematic review of randomised trials. B M C U rol 2002 Dec 12;2:14.

18. Sun J, Xiang H, Y ang LL, Chen J B. A review on steroidal 5alpha-reductase inhibitors for treatment of benign prostatic hyperplasia. Curr M ed Chem 2011;18(23):3576-89.

19. Wu C, Kapoor A. Dutasteride for the treatment of benign prostatic hyperplasia. Expert Opin Pharmacother $2013 \mathrm{Jul} ; 14(10): 1399-408$.

20. Tacklind J, Fink HA, M acdonald R, Rutks I, Wilt TJ. Finasteride for benign prostatic hyperplasia. Cochrane Database Syst Rev 2010(10):CD 006015.

21. Edwards JL. Diagnosis and management of benign prostatic hyperplasia. A merican family physician 2008 M ay 15;77(10):1403-10.

22. Gur S, Kadowitz PJ, Hellstrom WJ. Effects of 5-alpha reductase inhibitors on erectile function, sexual desire and ejaculation. Expert opinion on drug safety $2013 \mathrm{~J}$ an;12(1):81-90.

23. S. Gravas TB, A. B achmann, M. Drake, M. Gacci, C. Gratzke, S. M adersbacher, C. M amoulakis, K.A.O. Tikkinen. Guidelines on the $M$ anagement of N on- $N$ eurogenic $M$ ale Lower U rinary Tract Symptoms (LUTS), incl. B enign Prostatic Obstruction (B PO). European A ssociation of U rology 2015.** Latest EA U guidelines on the M anagement of $\mathrm{N}$ onNeurogenic M ale Lower U rinary Tract Symptoms (LUTS), incl. B enign Prostatic Obstruction (BPO).

24. Ernst E. The risk-benefit profile of commonly used herbal therapies: Ginkgo, St. J ohn's W ort, Ginseng, Echinacea, Saw Palmetto, and Kava. A nn Intern M ed 2002 J an 1;136(1):42-53.

25. Wilt TJ, Ishani A, Stark G, M acD onald R, Lau J, M ulrow C. Saw palmetto extracts for treatment of benign prostatic hyperplasia: a systematic review. JA M A $1998 \mathrm{~N} \mathrm{ov}$ 11;280(18):1604-9.

26. Lowe FC, K U JC. Phytotherapy in treatment of benign prostatic hyperplasia: a critical review. U rology 1996 J ul;48(1):12-20. 
27. K och E. Extracts from fruits of saw palmetto (Sabal serrulata) and roots of stinging nettle (Urtica dioica): viable alternatives in the medical treatment of benign prostatic hyperplasia and associated lower urinary tracts symptoms. Planta medica 2001 A ug;67(6):489-500.

28. M CNaughton-Collins M , B arry M J. M anaging patients with lower urinary tract symptoms suggestive of benign prostatic hyperplasia. A m J M ed 2005 Dec;118(12):1331-9. 29. Bent S, K ane C, Shinohara K, N euhaus J, Hudes ES, Goldberg H, et al. Saw palmetto for benign prostatic hyperplasia. N Engl J M ed 2006 Feb 9;354(6):557-66.

30. Gandaglia G, B riganti A, Gontero P, M ondaini N, N ovara G, Salonia A, et al. The role of chronic prostatic inflammation in the pathogenesis and progression of benign prostatic hyperplasia (BPH). BJU Int 2013 A ug;112(4):432-41.

31. Gerber GS, Zagaja GP, B ales GT, Chodak GW, Contreras BA. Saw palmetto (Serenoa repens) in men with lower urinary tract symptoms: effects on urodynamic parameters and voiding symptoms. U rology 1998 J un;51(6):1003-7.

32. Goepel M, Hecker U, Krege S, Rubben H, M ichel M C. Saw palmetto extracts potently and noncompetitively inhibit human al pha1-adrenoceptors in vitro. Prostate $1999 \mathrm{Feb}$ 15;38(3):208-15.

33. Oki T, Suzuki M, Nishioka $Y, Y$ asuda $A$, U megaki $K, Y$ amada $S$. Effects of saw pal metto extract on micturition reflex of rats and its autonomic receptor binding activity. J U rol 2005 A pr:173(4):1395-9.

34. Di Silverio F, M onti S, Sciarra A, V arasano PA, M artini C, Lanzara S, et al. Effects of long-term treatment with Serenoa repens (Permixon) on the concentrations and regional distribution of androgens and epidermal growth factor in benign prostatic hyperplasia. Prostate 1998 Oct 1;37(2):77-83.

35. A ggarwal S, Thareja S, V erma A, B hardwaj TR, Kumar M. A n overview on 5al phareductase inhibitors. Steroids 2010 Feb;75(2):109-53. 
36. Bartsch G, Rittmaster RS, K locker H. Dihydrotestosterone and the concept of 5al phareductase inhibition in human benign prostatic hyperplasia. Eur U rol 2000 A pr;37(4):367-80. 37. Drury JE, Di Costanzo L, Penning TM , Christianson DW. Inhibition of human steroid 5beta-reductase (AKR1D1) by finasteride and structure of the enzyme-inhibitor complex. J Biol Chem 2009 J ul 24;284(30):19786-90.

38. Clark RV, Hermann DJ, Cunningham GR, W ilson TH, M orrill BB, Hobbs S. M arked suppression of dihydrotestosterone in men with benign prostatic hyperplasia by dutasteride, a dual 5 al pha-reductase inhibitor. J Clin Endocr M etab 2004 M ay;89(5):2179-84.

39. Palin M F, Faguy M, L eH oux J G, Pelletier G. Inhibitory effects of Serenoa repens on the kinetic of pig prostatic microsomal 5al pha-reductase activity. Endocrine 1998 Aug;9(1):65-9.

40. Breu W, Hagenlocher M, Redl K, Tittel G, Stadler F, Wagner H. [A nti-inflammatory activity of sabal fruit extracts prepared with supercritical carbon dioxide. In vitro antagonists of cyclooxygenase and 5-lipoxygenase metabolism]. A rzneimittelforschung 1992 A pr;42(4):547-51.

41. Latil A, Libon C, Templier M J unquero D, Lantoine-A dam F, N guyen T. Hexanic lipidosterolic extract of Serenoa repens inhibits the expression of two key inflammatory mediators, M CP-1/CCL2 and V CAM -1, in vitro. BJU Int 2012 Sep;110(6 Pt B):E301-7.

42. Kyprianou $N, T u H$, Jacobs SC. A poptotic versus proliferative activities in human benign prostatic hyperplasia. Hum Pathol 1996 J ul;27(7):668-75.

43. Vacherot F, Azzouz M, Gil-Diez-D e-M edina S, Colombel M, De La Taille A, Lefrere Belda M A, et al. Induction of apoptosis and inhibition of cell proliferation by the lipidosterolic extract of Serenoa repens (LSESr, Permixon in benign prostatic hyperplasia. Prostate 2000 N ov $1 ; 45(3): 259-66$.

44. Iii Colado-V elazquez J, M ailloux-Salinas P, M edina-Contreras J, Cruz-Robles D, Bravo G. Effect of Serenoa Repens on Oxidative Stress, Inflammatory and Growth Factors in 
Obese W istar Rats with B enign Prostatic Hyperplasia. Phytotherapy research : PTR 2015 Oct;29(10):1525-31.

45. Thomson CD. A ssessment of requirements for selenium and adequacy of selenium status: a review. Eur J Clin Nutr 2004 M ar;58(3):391-402.

46. Schrauzer GN. The nutritional significance, metabolism and toxicology of selenomethionine. A dvances in food and nutrition research 2003;47:73-112.

47. Ellis DR, Salt DE. Plants, selenium and human health. Current opinion in plant biology 2003 J un;6(3):273-9.

48. Gramm HJ, K opf A, B ratter P. The necessity of selenium substitution in total parenteral nutrition and artificial alimentation. Journal of trace elements in medicine and biology : organ of the Society for M inerals and Trace Elements $1995 \mathrm{M}$ ar;9(1):1-12.

49. Zimmermann M B, K ohrle J. The impact of iron and selenium deficiencies on iodine and thyroid metabolism: biochemistry and relevance to public health. Thyroid : official journal of the A merican Thyroid A ssociation 2002 0ct;12(10):867-78.

50. El-Bayoumy $K$, Das A, Narayanan B, Narayanan N, Fiala ES, Desai D, et al. M olecular targets of the chemopreventive agent 1,4-phenylenebis (methylene)-selenocyanate in human non-small cell lung cancer. Carcinogenesis 2006 Jul;27(7):1369-76.

51. Clark LC, Combs GF, Jr., Turnbull BW, Slate EH, Chalker DK, Chow J, et al. Effects of selenium supplementation for cancer prevention in patients with carcinoma of the skin. A randomized controlled trial. Nutritional Prevention of Cancer Study Group. JA M A 1996 Dec 25;276(24):1957-63.

52. Y oshizawa K, Willett W C, M orris SJ, Stampfer MJ, Spiegelman D, Rimm EB, et al. Study of prediagnostic selenium level in toenails and the risk of advanced prostate cancer. J Natl Cancer Inst 1998 A ug 19;90(16):1219-24. 
53. M eyer F, Galan P, D ouville P, B airati I, K egle P, B ertrais S, et al. A ntioxidant vitamin and mineral supplementation and prostate cancer prevention in the SU.V I.M AX trial. Int J Cancer 2005 A ug 20;116(2):182-6.

54. Rayman M P. Selenium in cancer prevention: a review of the evidence and mechanism of action. The Proceedings of the Nutrition Society 2005 N ov;64(4):527-42.

55. Barrera L N, Cassidy A, J ohnson IT, B ao Y, B elshaw NJ. E pigenetic and antioxidant effects of dietary isothiocyanates and selenium: potential implications for cancer chemoprevention. The Proceedings of the Nutrition Society $2012 \mathrm{M}$ ay; $71(2): 237-45$.

56. Sies H, Stahl W. V itamins E and C, beta-carotene, and other carotenoids as antioxidants. The A merican journal of clinical nutrition 1995 Dec;62 (6 Suppl):1315S-21S. 57. Di M ascio P, Kaiser S, Sies H. Lycopene as the most efficient biological carotenoid singlet oxygen quencher. A rchives of biochemistry and biophysics $1989 \mathrm{~N}$ ov 1;274(2):532-8. 58. Clinton SK, E menhiser C, Schwartz SJ, B ostwick DG, W illiams A W, M oore BJ, et al. cis-trans lycopene isomers, carotenoids, and retinol in the human prostate. Cancer E pidemiol Biomarkers Prev 1996 Oct; 5(10):823-33.

59. Palan P, Naz R. Changes in various antioxidant levels in human seminal plasma related to immunoinfertility. Archives of andrology $1996 \mathrm{M}$ ar-A pr;36(2):139-43.

60. Goyal A, Delves GH, Chopra M, L waleed BA, Cooper AJ. Prostate cells exposed to Iycopene in vitro liberate lycopene-enriched exosomes. BJU Int 2006 0ct;98(4):907-11. 61. Bowen P, Chen L, Stacewicz-Sapuntzakis M, Duncan C, Sharifi R, Ghosh L, et al. Tomato sauce supplementation and prostate cancer: Iycopene accumulation and modulation of biomarkers of carcinogenesis. Experimental biology and medicine $2002 \mathrm{~N} \mathrm{ov} ; 227(10): 886-93$.

62. Siler U, Barella L, Spitzer V, Schnorr J, Lein M, Goralczyk R, et al. Lycopene and vitamin E interfere with autocrine/paracrine loops in the Dunning prostate cancer model. FA SEB J 2004 J un;18(9):1019-21. 
63. Ford NA, Erdman JW, Jr. A re lycopene metabolites metabolically active? A cta biochimica Polonica 2012;59(1):1-4.

64. Giovannucci E. Tomato products, lycopene, and prostate cancer: a review of the epidemiological literature. The J ournal of nutrition 2005 A ug;135(8):2030S-1S.

65. Herzog A, Siler U, Spitzer V, Seifert N, Denelavas A, Hunziker PB, et al. Lycopene reduced gene expression of steroid targets and inflammatory markers in normal rat prostate. FASEB J 2005 Feb;19(2):272-4.

66. Gerster H. The potential role of lycopene for human health. J ournal of the A merican College of Nutrition 1997 A pr;16(2):109-26.

67. Huang CS, Liao JW, Hu M L. Lycopene inhibits experimental metastasis of human hepatoma SK -Hep-1 cells in athymic nude mice. The Journal of nutrition 2008 M ar;138(3):538-43.

68. Clinton SK. Lycopene: chemistry, biology, and implications for human health and disease. Nutrition reviews 1998 Feb;56(2 Pt 1):35-51.

69. Ford NA, Elsen AC, Zuniga K, Lindshield BL, Erdman JW, Jr. Lycopene and apo-12'lycopenal reduce cell proliferation and alter cell cycle progression in human prostate cancer cells. Nutrition and cancer 2011;63(2):256-63.

70. Giovannucci E, A scherio A, Rimm EB, Stampfer MJ, Colditz GA, Willett WC. Intake of carotenoids and retinol in relation to risk of prostate cancer. J Natl Cancer Inst $1995 \mathrm{Dec}$ 6;87(23):1767-76.

71. Bonvissuto G, M inutoli L, M orgia G, Bitto A, Polito F, I rrera N, et al. Effect of Serenoa repens, lycopene, and selenium on proinflammatory phenotype activation: an in vitro and in vivo comparison study. U rology 2011 J an;77(1):248 e9-16.

72. A Itavilla D, Bitto A, Polito F, Irrera N, M arini $\mathrm{H}, \mathrm{A}$ rena $\mathrm{S}$, et al. The combination of Serenoa repens, selenium and lycopene is more effective than serenoa repens alone to prevent hormone dependent prostatic growth. J U rol 2011 Oct;186(4):1524-9. 
73. Gerstenbluth RE, Seftel AD, MacLennan GT, Rao RN, Corty EW, Ferguson K, et al. Distribution of chronic prostatitis in radical prostatectomy specimens with up-regulation of bcl-2 in areas of inflammation. J U rol 2002 M ay;167(5):2267-70.

74. Itoh N, Patel U, Skinner M K. Developmental and hormonal regulation of transforming growth factor-alpha and epidermal growth factor receptor gene expression in isolated prostatic epithelial and stromal cells. Endocrinology $1998 \mathrm{M}$ ar;139(3):1369-77.

75. Prenzel N, Fischer OM, Streit S, Hart S, Ullrich A. The epidermal growth factor receptor family as a central element for cellular signal transduction and diversification. Endocr Relat Cancer $2001 \mathrm{M}$ ar;8(1):11-31.

76. Di Lorenzo G, Tortora G, D 'A rmiento FP, De Rosa G, Staibano S, A utorino R, et al. Expression of epidermal growth factor receptor correlates with disease relapse and progression to androgen-independence in human prostate cancer. Clin Cancer R es 2002 Nov;8(11):3438-44.

77. Xiao X, Wu J, Zhu X, Zhao P, Zhou J, Liu Q Q, et al. Induction of cell cycle arrest and apoptosis in human nasopharyngeal carcinoma cells by ZD 6474, an inhibitor of VEGFR tyrosine kinase with additional activity against EGFR tyrosine kinase. Int J Cancer 2007 N ov $1 ; 121(9): 2095-104$.

78. Bates DO, Curry FE. V ascular endothelial growth factor increases hydraulic conductivity of isolated perfused microvessels. A m J Physiol 1996 Dec;271(6 Pt 2):H 2520-8. 79. Jackson M W, B entel J M, Tilley WD. V ascular endothelial growth factor (VEGF) expression in prostate cancer and benign prostatic hyperplasia. J U rol 1997 J un;157(6):23238.

80. Galban S, B rady GF, Duckett CS. Caspases and IA PS: a dance of death ensures cell survival. Mol Cell 2008 Nov 21;32(4):462-3.

81. M antovani F. Serenoa repens in benign prostatic hypertrophy: analysis of 2 Italian studies. M inerva U rol N efrol 2010 Dec;62(4):335-40. 
82. A zimi $H, K$ hakshur A A, A ghdasi I, Fallah-Tafti M, A bdollahi M. A review of animal and human studies for management of benign prostatic hyperplasia with natural products: perspective of new pharmacological agents. Inflammation \& allergy drug targets 2012 Jun;11(3):207-21.

83. Bertaccini A, Giampaoli M, Cividini R, Gattoni GL, Sanseverino R, Realfonso T, et al. Observational database serenoa repens (DOSSER): overview, analysis and results. A multicentric SIU rO (Italian Society of Oncological U rology) project. A rch Ital U rol Androl 2012 Sep;84(3):117-22.

84. Boyle P, Robertson C, Lowe F, R oehrborn C. U pdated meta-analysis of clinical trials of Serenoa repens extract in the treatment of symptomatic benign prostatic hyperplasia. BJU Int 2004 A pr;93(6):751-6. * M eta-analysis on clinical trials of Serenoa repens extrat in the treatment of $\mathrm{BPH}$

85. Tacklind J, M acD onald R, Rutks I, W ilt TJ. Serenoa repens for benign prostatic hyperplasia. Cochrane Database Syst Rev 2009(2):CD 001423.

86. Barry MJ, M eleth S, Lee JY, K reder KJ, A vins A L, Nickel JC, et al. Effect of increasing doses of saw palmetto extract on lower urinary tract symptoms: a randomized trial. JAM A 2011 Sep 28;306(12):1344-51. * Randomized trial on Saw palmetto effects on LUTS 87. M acD onald R, Tacklind JW, Rutks I, W ilt TJ. Serenoa repens monotherapy for benign prostatic hyperplasia (BPH): an updated Cochrane systematic review. BJU Int 2012 J un; 109(12):1756-61.

88. Carraro JC, Raynaud JP, K och G, Chisholm GD, Di Silverio F, Teillac P, et al. Comparison of phytotherapy (Permixon) with finasteride in the treatment of benign prostate hyperplasia: a randomized international study of 1,098 patients. Prostate 19960 ct;29(4):23140; discussion 41-2. 
89. Sinescu I, Geavlete P, M ultescu R, Gangu C, M iclea F, Coman I, et al. Long-term efficacy of Serenoa repens treatment in patients with mild and moderate symptomatic benign prostatic hyperplasia. U rol Int 2011;86(3):284-9.

90. Pytel Y A, V inarov A, Lopatkin N, Sivkov A, Gorilovsky L, Raynaud JP. Long-term clinical and biologic effects of the lipidosterolic extract of Serenoa repens in patients with symptomatic benign prostatic hyperplasia. A dvances in therapy $2002 \mathrm{~N} \mathrm{ov}-\mathrm{Dec} ; 19(6): 297-$ 306.

91. Morgia G, Russo GI, V oce S, Palmieri F, Gentile M, Giannantoni A, et al. Serenoa repens, Iycopene and selenium versus tamsulosin for the treatment of LUTS/B PH. A n Italian multicenter double-blinded randomized study between single or combination therapy (PROCOM B trial). Prostate 2014 Nov;74(15):1471-80. * M ost recent randomized trial on the efficacy of Serenoa repens, lycopene and selenium versus tamsulosin for the treatment of LUTS/BPH

92. Morgia G, M ucciardi G, Gali A, M adonia M, M archese F, Di B enedetto A, et al. Treatment of chronic prostatitis/chronic pelvic pain syndrome category IIIA with Serenoa repens plus selenium and lycopene (Profluss) versus S. repens al one: an Italian randomized multicenter-controlled study. Urol Int 2010;84(4):400-6.

93. M orgia G, Cimino S, Favilla V, Russo GI, Squadrito F, M ucciardi G, et al. Effects of Serenoa repens, selenium and lycopene (Profluss(R)) on chronic inflammation associated with benign prostatic hyperplasia: results of "FLOG" (Flogosis and Profluss in Prostatic and Genital Disease), a multicentre Italian study. Int B raz J U rol 2013 M ar-A pr;39(2):214-21.

94. Gagnier JJ, Boon H, Rochon P, M oher D, Barnes J, B ombardier C, et al. Recommendations for reporting randomized controlled trials of herbal interventions: Explanation and elaboration. J ournal of clinical epidemiology 2006 Nov;59(11):1134-49. 
95. A gbabiaka TB, Pittler M H, W ider B, Ernst E. Serenoa repens (saw palmetto): a systematic review of adverse events. Drug safety 2009;32(8):637-47. ** M ost recent systematic review on Serenoa repens' adverse events

96. Izzo A A. Interactions between herbs and conventional drugs: overview of the clinical data. M edical principles and practice : international journal of the K uwait U niversity, Heal th Science Centre 2012;21(5):404-28. ** M ost recent report on Serenoa repens' interaction with other drugs

97. M arkowitz JS, D onovan JL, Devane CL, T aylor R M , Ruan Y, W ang JS, et al.

M ultiple doses of saw palmetto (Serenoa repens) did not alter cytochrome P450 2D 6 and 3A 4 activity in normal volunteers. Clin Pharmacol Ther 2003 Dec;74(6):536-42.

98. Gorski J C, Huang SM, Pinto A, Hamman M A, Hilligoss J K, Zaheer NA, et al. The effect of echinacea (Echinacea purpurea root) on cytochrome P450 activity in vivo. Clin Pharmacol Ther 2004 Jan;75(1):89-100.

99. Roehrborn CK, S. Noble, W. Lucia, M Slawin, M. M cV ary, K. K usek, J. Nyberg, L. The impact of acute or chronic inflammation in baseline biopsy on the risk of clinical progression of BPH: results from the M TOPS study. J U rol 2005;173(5). 


\begin{tabular}{|l|l|l|l|l|}
\hline $\begin{array}{l}\text { Targets on } \\
\text { Prostate }\end{array}$ & Serenoa Repens & Selenium & Lycopene & $\begin{array}{l}\text { Serenoa Repens, } \\
\text { Lycopene, Selenium } \\
\text { Association }\end{array}$ \\
\hline $\begin{array}{l}\alpha \text { ladrenergic } \\
\text { receptors }\end{array}$ & $\begin{array}{l}\text { Blockade of } \\
\alpha \text { ladrenergic } \\
\text { receptors }\end{array}$ & none & none & $\begin{array}{l}\text { Possible effect due to } \\
\text { Serenoa Repens }\end{array}$ \\
\hline $\begin{array}{l}\text { M uscarinic } \\
\text { receptors }\end{array}$ & $\begin{array}{l}\text { Anti-muscarinic } \\
\text { activity }\end{array}$ & none & none & $\begin{array}{l}\text { Possible effect due to } \\
\text { Serenoa Repens }\end{array}$ \\
\hline $5 \alpha$-reductase & $\begin{array}{l}\text { Enzyme } \\
\text { Inhibition }\end{array}$ & none & $\begin{array}{l}\text { Inhibition of } 5 \alpha- \\
\text { reductase } \\
\text { signalling }\end{array}$ & $\begin{array}{l}\text { Inhibition of enzyme } \\
\text { plus } 5 \alpha \text {-reductase } \\
\text { signalling }\end{array}$ \\
\hline $\begin{array}{l}\text { Oxidative } \\
\text { stress }\end{array}$ & $\begin{array}{l}\text { Antioxidant } \\
\text { activity }\end{array}$ & $\begin{array}{l}\text { Antioxidant } \\
\text { activity }\end{array}$ & $\begin{array}{l}\text { Antioxidant } \\
\text { activity }\end{array}$ & $\begin{array}{l}\text { Increased antioxidant } \\
\text { activity }\end{array}$ \\
\hline Inflammation & $\begin{array}{l}\text { Antiinflammatory } \\
\text { effects }\end{array}$ & $\begin{array}{l}\text { Antiínflammatory } \\
\text { activity }\end{array}$ & $\begin{array}{l}\text { Antiinflammatory } \\
\text { effects }\end{array}$ & $\begin{array}{l}\text { Increased reduction of } \\
\text { inflammation }\end{array}$ \\
\hline $\begin{array}{l}\text { Cell } \\
\text { proliferation }\end{array}$ & Inhibition & Inhibition & Inhibition & $\begin{array}{l}\text { Enhanced anti- } \\
\text { proliferative effects }\end{array}$ \\
\hline
\end{tabular}

Table 1 - Effects of Serenoa Repens, L ycopene and Selenium Either A lone Or in A ssociation, on Prostate Gland 


\begin{tabular}{|c|c|c|c|c|c|c|c|c|c|c|c|c|c|}
\hline \multirow[b]{2}{*}{$\begin{array}{l}\text { Measure } \\
\end{array}$} & \multicolumn{3}{|c|}{ MORGIA et tal (88) Median change from baseline (range) } & \multicolumn{2}{|c|}{$\begin{array}{l}\text { MORGIA etal (89) Percentchange } \\
\text { from baseline }\end{array}$} & \multicolumn{3}{|c|}{ BENT etal| (27) Median change from baseline } & \multicolumn{3}{|c|}{ BOY LE e eta (185) Median change from baseline } & \multicolumn{2}{|c|}{$\begin{array}{l}\text { BERRY et tlll 86) Median change } \\
\text { from baseline (range) }\end{array}$} \\
\hline & $\begin{array}{l}\text { Serenoa repens, } \\
\text { lycopene and } \\
\text { selenium } \\
\text { (PROFLUSS } \circledast \text { ) }\end{array}$ & Tamsulosin & $\begin{array}{l}\text { Serenoa repens, } \\
\text { lycopene and selenio } \\
\text { (PROFLUSS(@)++ } \\
\text { Tamsulosin }\end{array}$ & 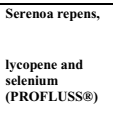 & $\begin{array}{l}\text { Serenoa } \\
\text { repens }\end{array}$ & $\begin{array}{l}\text { Saw } \\
\text { Palmetto }\end{array}$ & Placebo & $\begin{array}{l}\text { Difference } \\
\text { betreen } \\
\text { Groups }\end{array}$ & Permixon & Placebo & $\begin{array}{l}\text { Difference } \\
\text { betreen } \\
\text { Groups }\end{array}$ & $\begin{array}{l}\text { Saw } \\
\text { Palmetto }\end{array}$ & Placebo \\
\hline $\begin{array}{ll}\text { AUASI } \\
\text { scree }\end{array}$ & & & & & & $0.0 .35 \cdot \pm$ & 0.0 .72 & $\begin{array}{l}0.04-0.93 \text { to } \\
1.01)^{2}\end{array}$ & & & & 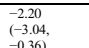 & \\
\hline IPSS & $-3.0(-13$ to 3.0$)$ & $-3.0(-2000.0)$ & $-4.0(-17705.0)$ & $.50 .32 \%$ & $-10.88 \%$ & & & & $-0.22 \pm 0.52$ & $\begin{array}{l}-4.41 \pm \\
0.57 \\
\end{array}$ & $0.389 \pm 0.302$ & & \\
\hline 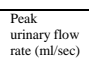 & $2.0(-5,3 ; 111)$ & $2.0(-8 ; 15)$ & $2.3(-3 ; 13)$ & $+10.59 \%$ & $+0.68 \%$ & 0.42 & 0.34 & $\begin{array}{l}0.43(-0.52 \text { to } \\
1.38)^{-}\end{array}$ & $1.00 \pm 0.49$ & $1.25 \pm 0.48$ & & & ${ }^{-0.79(-1.58,}$ \\
\hline 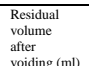 & $-10.0(-70 ; 90)$ & $-30.0(-100 ; 80)$ & $-34.5(-112 ; 100)$ & & & $\begin{array}{l}14.10 \\
7.24\end{array}$ & $\begin{array}{l}18.62 \\
7.14\end{array}$ & $\begin{array}{l}-4.51(-24.44 \\
\text { to } 15.42)\end{array}$ & & & & & $\begin{array}{l}1.17(-33.00, \\
34.00)\end{array}$ \\
\hline $\begin{array}{l}\text { Prostate } \\
\text { volume }(m)\end{array}$ & $-1.5(-14 ; 20)$ & $-1.0(-16 ; 12)$ & $-2.5(-15 ; 20)$ & & & 3.76 & 0.98 & $\begin{array}{l}-1.22(-3.90 \text { to } \\
1.47)\end{array}$ & & & & & \\
\hline 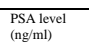 & $0(-1.40 ; 2.20)$ & $-0.09(-2.5 ; 3.13)$ & $-0.16(-1.74 ; 2.55)$ & $-26.81 \%$ & $-7.11 \%$ & & & & & & & $\begin{array}{l}0.32(-0.08, \\
0.73)\end{array}$ & $\begin{array}{l}-0.19(-0.53, \\
0.14)^{-}\end{array}$ \\
\hline Nocturia & & & & & & & & & & & $0.186 \pm 0.077$ & $\begin{array}{l}-0.36 \\
(-0.72,0) \\
\end{array}$ & $0.13)$ - 0.0 .44 \\
\hline $\begin{array}{l}\text { BppImpact } \\
\text { Index }\end{array}$ & & & & & & & & & & & & $\begin{array}{l}-0.81 \\
\substack{-0.16 .16 \\
-0.49)}\end{array}$ & 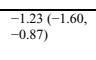 \\
\hline $\begin{array}{l}\text { AUASI } \\
\text { QOL }\end{array}$ & & & & & & & & & & & & $\begin{array}{l}-0.34 \\
(-0.52, \\
-0.16)\end{array}$ & $\begin{array}{l}-0.49(-0.67, \\
-0.31)\end{array}$ \\
\hline PSSS Qol & $1(-4 ; 3)$ & $1(-5 ; 2)$ & $1(-5 ; 3)$ & & & & & & & & & & \\
\hline $\begin{array}{l}\text { TiEk erectile } \\
\text { scale }\end{array}$ & $0.3(-19.0008 .0)$ & $0.2(-5.00040 .0)$ & $0.7(-4.0$ to 11.0$)$ & & & & & & & & & $\begin{array}{l}-0.52 \\
(-1.63,0.59)\end{array}$ & $\begin{array}{l}-1.06(-2.11, \\
-0.02)\end{array}$ \\
\hline$\overline{E j Q}$ & $-0.22(-3.0$ to 1.0$)$ & $\begin{array}{l}-0.27(-2.010 \\
3.0)\end{array}$ & $-0.36(-2.0$ to 2.0$)$ & & & & & & & & & & \\
\hline 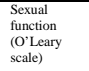 & & & & & & & $\begin{array}{l}0.07 \\
0.10\end{array}$ & $\begin{array}{l}-0.13(-0.40 \text { to } \\
0.14)^{-}\end{array}$ & & & & & \\
\hline $\begin{array}{ll}\text { NIH-CPSI } \\
\end{array}$ & & & & $-51.64 \%$ & & $\pi$ & & & & & & & \\
\hline 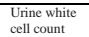 & & & & & $-6.28 \%$ & & & & & & & & \\
\hline
\end{tabular}

Table 2 - Summary of main cited studies 
BOX

\section{Message for the clinic}

Serenoa Repens is a phytotherapeutic agent ameliorating BPH/LUTS. Patients bothered by prostatic inflammation and prostatis most benefit from Serenoa Repens +Lycopene+Selenium. The combination of Serenoa Repens + Lycopene+Selenium and an alpha-blocker is an effective option to target BPH/LUTS. 